\title{
Effect of some irrigation and fertilization treatments on growth and productivity of winter tomato grown under low tunnils
}

\author{
Lotfy A. Badr, Moustafa H. M. Mohamed and Mohamed S. A. Abdelmoati \\ Horticulture Dept., Fac. Of Agric., Benha university
}

\begin{abstract}
Two field experiments were carried out during the two successive seasons of 2015/2016 and 2016/2017 at the Private Farm on Wade El-Moulak region, Ash sharqiyah Governorate, Egypt, to assess the effect of drip irrigation rates and organic and mineral nitrogen fertilizers as well as different interaction among them on growth, yield and chemical constituents of tomato plants hybrid GS12 F1. The drip irrigation treatments began of transplanting and were added in the morning at two times/week up to end of May month, thus number of irrigation to season was 52 ones. The amounts of water were added using water counter and pressure counter at 1 bar. The amounts of calculate water were added to different treatments, express through drippers $(4 \mathrm{~L} / \mathrm{h})$ to give such amounts of water. Obtained results showed that the effect of fertilization treatments on vegetative growth character is tics of tomato plants.
\end{abstract}

Key words: irrigation, fertilization, growth, tomato, low tunnils.

\section{Introduction}

Tomato (Lycopersicon esculentum Mill.) is one of the most important vegetables worldwide. As it is a relatively short duration crop and gives a high yield, it is economically attractive and the area under cultivation is increasing daily Moreover, tomatoes contribute to a healthy, wellbalanced diet and having rich in minerals, vitamins, essential amino acids, sugars and dietary fibres. Tomato (Lycopersicon esculentum, (Mill.) L.) is one of the most important vegetable crops grown in Egypt for fresh consumption and processing. The total cultivated area of tomato in Egypt was about 459,283 fed. during 2003 season* which produced 7,140,198 tons with average of 15.55 tons/feddan.

As a good sources of plant nutrient supply and as good soil conditioners. Contains much vitamin B and $\mathrm{C}$, iron and phosphorus. Tomato fruits are consumed fresh in salads or cooked in sauces, soup and meat or fish dishes. They can be processed into purées, juices and ketchup. Canned and dried tomatoes are economically important processed products.

Water is one of the major resources that limit agricultural developments especially in the arid lands. The Egyptian water resources are not sufficient related to the agricultural development in Egypt.

As the Egyptian water share from the River Nile is limited by $55.5 \times 10^{9} \mathrm{~m}^{3} /$ year, the necessity to rationalize the irrigation water needs no emphasis. About $85 \%$ of the Egyptian water balance is used for agricultural purpose. Drip irrigation system has already been established as recommended method for vegetable production especially under sandy soil conditions. Drip irrigation besides giving a saving of $32 \%$ as compared with surface irrigation system. During the last decades, considerable research efforts have gone into the study of plant water relations, microclimatology and evapotranspiration. Using chemical fertilizers (NP) in agriculture specially in vegetable crops causing hazardous effect for human, plant and animals, and led to depression in the activities of nitrogen fixing bacteria and also in activities of phosphorus bacteria ( Waksman, 1952). Similar to frequent application of water, optimum split applications of fertilizer improves quality and quantity of crop yield than the conventional practice .The capital investments in the construction of irrigation systems of new type decrease by 20-60\% in comparison with the systems of regular operation. This reduction happens due to water flow distribution and minimization of diameters of the water conveyance network and also due to elimination of thorough water treatment necessary for drip irrigation systems. The empirical studies and optimization calculations have shown that the minimum discharge capacity and, hence, the minimum coefficient for the water conveyance network and equipment are provided by the system of continuous operation, when the degree of equipment use in time is equal to one. Energy consumption by the systems of pulse localized irrigation is much lower than by drip irrigation systems, because the required pressure for a design module is less than 3-5 mm of water column .A great attention has been directed towards the use of organic fertilizers to reduce plant and soil contaminations with mineral fertilizers, improve the fertility of soil and reduce nutrient losses. In addition, the organic fertilizers were considered as good sources of plant nutrient supply and good soil conditioners. Addition of organic matter, can improve all soil properties; such as water holding capacity, soil aggregation, stability, soil fertility, and increase cation exchange capacity. Also, organic fertilizers were used to decrease soil $\mathrm{pH}$ and increase the availability of major and minor nutrients 
(Tahoun et al, 2000). Some stated that application of organic manure increased dry weight/plant; N, P and $\mathrm{K}$ contents; number of fruits/plant; average fruit weight as well as yield/plant and feddan (Mohsen, 2006; Olaniyi and Ajibola, 2008; Agyeman et al., 2014; Ilupeju et al., 2015; and Yousafzai et al., 2016 on tomato). Therefore, this study was carried out to study the responses of growth, yield, fruit quality and chemical constituents of tomato plants to various sources of organic and mineral nitrogen with biofertilizers treatments.

\section{Materials and Methods}

Two field experiments were carried out during the two successive seasons of 2015/2016 and
2016/2017 at the Private Farm on Wade El-Moulak region, Ash sharqiyah Governorate, Egypt, to assess the effect of drip irrigation rates and organic and mineral nitrogen fertilizers as well as different interaction among them on growth, yield and chemical constituents of tomato plants hybrid $\mathrm{GS}_{12}$ $F_{1}$. The drip irrigation treatments began of transplanting and were added in the morning at two times/week up to end of May month, thus number of irrigation to season was 52 ones. The amounts of water were added using water counter and pressure counter at 1 bar. The amounts of calculate water were added to different treatments, express through drippers $(4 \mathrm{~L} / \mathrm{h})$ to give such amounts of water which presented in Schedule 2.

Schedule 2. The amount of water, the time needed to give such amounts and amounts of water supply at every irrigation.

\begin{tabular}{lll}
\hline Treatments $\left(\mathbf{m}^{\mathbf{3}} / \mathbf{f e d}\right)$ & Time needs $(\mathbf{h})$ & Water supply every irrigation $\left(\mathbf{m}^{\mathbf{3}} / \mathbf{f e d}\right)$ \\
\hline 1456 & 1 & 28 \\
2184 & 1.5 & 42 \\
2912 & 2 & 56 \\
3640 & 2.5 & 70 \\
\hline
\end{tabular}

Seeds of hybrid GS12 F1were sown in nursery on $15^{\text {th }}$ Oct. in foam trays and seedlings were tr6ansplanted (with 3-4 true leaves i.e. after 45 days) from sowing on $2^{\text {st }}$ Dec. for $1^{\text {st }}$ and $2^{\text {nd }}$ seasons.

The experimental unit area was $36 \mathrm{~m}^{2}(7.2 \times 5$ $\mathrm{m})$ and each unit contained six rows with $5 \mathrm{~m}$ length for each and $120 \mathrm{~cm}$ width of them, four inner rows were possessed for yield determination, whereas the two outer rows were devoted to plant growth parameter. The distance between seedling was 50 $\mathrm{cm}$.

This experiment included 16 treatments as follow: A- Drip irrigation rates

$1-1456 \mathrm{~m}^{3} / \mathrm{fed}$

2- $2184 \mathrm{~m}^{3} / \mathrm{fed}$

3- $2912 \mathrm{~m}^{3} / \mathrm{fed}$

4-3640 $\mathrm{m}^{3} / \mathrm{fed}$

B- Organic and mineral nitrogen

1- $135 \mathrm{~kg}$ (45 $\mathrm{N}$ unit) nitrate ammonium (25\% mineral $\mathrm{N})+50.4 \mathrm{~m}^{3}$ chicken manure/fed $(75 \%$ organic $\mathrm{N}$ ).

2- $269 \mathrm{~kg}(90 \mathrm{~N}$ unit) nitrate ammonium (50\% mineral $\mathrm{N})+33.6 \mathrm{~m}^{3}$ chicken manure/fed $(50 \%$ organic $\mathrm{N}$ ).

3- $403 \mathrm{~kg}(135 \mathrm{~N}$ unit) nitrate ammonium $(75 \%$ mineral $\mathrm{N})+16.8 \mathrm{~m}^{3}$ chicken manure/fed $(25 \%$ organic $\mathrm{N})$.

4- $538 \mathrm{~kg}(180 \mathrm{~N}$ unit) nitrate ammonium (100\% mineral $\mathrm{N}$ ).

Chicken manure (as organic $\mathrm{N}$ ) was added at the time of soil preparation. The source of mineral nitrogen fertilizer was nitrate ammonium $(33.5 \% \mathrm{~N})$. Amount of the mineral nitrogen, for every treatment, was divided into eight equal portions ( 8 frequencies) and weekly applied starting from 15 days after transplanting.

All experimental units received equal amounts of $\mathrm{P}$ and $\mathrm{K}$ fertilizers at the rates of 450 and 200 $\mathrm{kg} / \mathrm{fed}$ as a calcium superphosphate $\left(15.5 \% \quad \mathrm{P}_{2} \mathrm{O}_{5}\right)$ and potassium sulphate $\left(48 \% \mathrm{~K}_{2} \mathrm{O}\right)$, respectively. At the times, one third of $\mathrm{P}$ and $\mathrm{K}$ fertilizers were added at the time of soil preparation. The other two thirds were divided into three equal portions and added every 15 days. The first portion was added after 30 days from transplanting. The other normal agricultural treatments of growing tomato plants were practiced.

These treatments were arranged in split plot design with three replicates in both seasons. Drip irrigation rates were assigned at random in the main plots, while sub plots were devoted to organic and mineral nitrogen.

\section{Data recorded}

\section{A. Plant Growth}

\section{a. Morphological characters}

A random sample of six plants from each plot was taken at age 80 days and the following data were recorded: Plant height $(\mathrm{cm})$, Number of leaves/plant And Number of branches/plant, Fresh weight, Fresh weight of leaves/plant $(\mathrm{g})$, Fresh weight of branches/plant $(\mathrm{g})$ and Fresh weight of whole plant (g)

b. Dry weight, Dry weight of leaves/plant (g), Dry weight of branches/plant (g) and Dry weight of whole plant $(\mathrm{g})$ 


\section{B. Fruit Yield}

Mature fruits were continuously harvested when reached suitable maturity stages, and the following data were recorded: Number of fruits/plant, Average fruit weight (g), Fruit yield/plant (kg), Fruit yield/fed (ton):

Total fruit yield was calculated on the basis of total yield along harvesting at full-ripe maturity stages by summing (the sum of all harvests).

\section{5- Fruit quality:}

5.1 Total soluble solids percentage (TSS \%): It was determined in fruit juice by Carle zeis Refractometer. 5.2 Ascorbic acid (Vit. C $\mathbf{~ m g / 1 0 0 ~} \mathbf{~ m l}$ juice): It was determined in fruit juice using 2,6,Dichlorophenol indophenol dye (A.O.A.C., 1990).

5.3 Tetratable acidity (\%): Tetratable acidity was determined by the titration against $(\mathrm{NaOH})$ using phenolphthalin (Phth) as indicator according to the method described in (A.O.A.C., 1990).

\section{Minerals Content and Total protein}

Total nitrogen, phosphorus and potassium were determined in dry plant according to A.O.A.C. (2005)

Total protein (\%): It was determined as nitrogen content and converted to its equivalent protein content by multiplying X 6.25 .

\section{NPK Uptake}

NPK uptake were calculated as NPK contents on dry weight basis, according to (Klute1986 and Page et al. 1982).

Statistical Analysis

All obtained data were statistically analyzed according to the technique of analysis of variance (ANOVA) for the split plot design by using means of "MSTAT-C" computer software package. Least Significant Difference (LSD) method was used to test the differences between treatment means at $5 \%$ level of probability as described by Snedecor and Cochran (1980).

\section{Result and Discussion}

\section{4- Effect of irrigation quantity and fertilization treatments on:}

4-1-Vegetative growth characters.

Data illustrated in Tables (1,2 and 3) show the effect of irrigation quantity, fertilization treatments and their interaction on vegetative growth traits of tomato plants during 2015 and 2016 seasons. 4-1-1- Effect of irrigation quantity.

Data showed in Tables $(1,2$, and 3 ) indicate that all the studied growth characters expressed as plant height, number of leaves per plant, number of branches per plant, leaves fresh (g/plant), branches fresh weight (g/plant), total plant fresh weight (g/plant), leaves dry weight (g/plant), branches dry weight $(\mathrm{g} /$ plant) and total plant dry weight ( $\mathrm{g} /$ plant) were significantly increased with increasing irrigation water amount up to $2912 \mathrm{~m}^{3} / \mathrm{fed}$. During the growing season. In this concern the highest values in all a fore mentioned growth parameters were attained as a result of applying $2912 \mathrm{~m}^{3} / \mathrm{fed}$. compared with the other used irrigation water quantity, i.e.,1456, 2184 and $3640 \mathrm{~m}^{3} / \mathrm{fed}$. obtained results are true during 2015 and 2016 seasons of study .Such increases in plant growth traits due to increasing the amount of water irrigation may be due to the role of water in enhancing the physiological processes and increasing the solubility and uptake of macronutrients (Tables 5 and 6) which incorporated in the formation of cells and consequently increasing the plant growth. Obtained results are in agreement with those reported by EL-Tantawy and EL-Beik (2007), Ghassemi-Golezani and Mardfar (2008), El-Noemani et al. (2010), Abd El-Aal et al. (2011), and Marzouk et al. (2016) who showed that increase water quantity led to a significant increase of plant growth (plant height, number of branches and leaves /plant).Also, Amer et al. (2002a\&b) recorded that increasing irrigation levels (80, 100 and 120\% Ep.) increased mineral contents (NPK) in leaves, branches and whole plant. Ismail (2004) explained that drip irrigation at rates of 800,1200 and $1600 \mathrm{~m}^{3}$ water / fed. Significantly increased NPK and protein contents.

\section{4-1-2- Effect of fertilization treatments.}

Concerning the effect of fertilization treatments on vegetative growth character is tics of tomato plants, the same data shown in Tables (1,2 and 3) clear that all the studied vegetative growth parameters, i.e. plant height, number of leaves per plant, number of branches per plant, leaves fresh weight, branches fresh weight, total plant fresh weight weight, leaves dry weight, branches dry weight and total plant dry weight were positively affected due to the application of both mineral. NPK fertilization and organic manure. In this regard, application NPK mineral fertilization in a single form at the recommended dose or in combination with organic manure at different rates led to a significant differences between all the measured growth aspects of tomato plants. In this connection, the highest values for all recorded vegetative growth characters of plant were obtained as a result of using $75 \%$ NPK mineral fertilizers. From the recommended doses plus organic manure, meanwhile the lowest values were obtained as a result of using. $25 \%$ NPK mineral fertilizer pluse organic manure. obtained results are true during both seasons of study. Application of NPK mineral fertilizers and organic manure increased the macro-elements content (N,P and K) in different plant parts (Tables 5 and 6 ) which play the major role in increasing cell decision and cell elongation and consistently increased plant growth. Obtained results are coincided with those reported by El-Shobaky (2002), Abd El-Rahman (2001), ElRobae (2003), EINaggar (2004), El-Mansi et al. 
(2004), Baddour (2010) and Muhammad et al. (2011) in case of mineral nitrogen fertilizer and Fattahallah (1992a), Abd-Allah et al., (2001), Abd El- Hakeem (2003), El-Mansi et al., (2004), Mohsen (2006), Olaniyi and Ajibola (2008), Ayeni et al (2010), Agyeman et al. (2014), Mojeremane et al. (2016) ans Yousafzai et al. (2016) in case of organic manure.

\section{4-1-3-Effect of the interaction.}

As for the effect of the interaction treatments the same data in Tables (1,2 and 3) indicate that there were significant differences in all measured vegetative growth parameters during both seasons of growth due to the interaction between the different studied treatments. In this respect, irrigating tomato plants with $2912 \mathrm{~m}^{3} / \mathrm{fed}$. of water irrigation and fertilizing the plants with $75 \%$ NPK mineral fertilizers from the highest values in the different vegetative growth traits (plant height, number of leaves per plant, number of branches per plant, leaves fresh weight, branches fresh weight, total plant fresh weight, leaves dry weight, branches dry weight and total plant dry weight) during the two seasons of growth. Whereas, the lowest values were recorded in the case of irrigation with $1456 \mathrm{~m}^{3} / \mathrm{fed}$ water irrigation and fertilizer the plants with $25 \%$ NPK mineral fertilizers + organic manure. Obtained results are true during both seasons of study. In this respect, El-Mansi et al. (2004), Mohsen (2006), Mahila et al. (2010) and Dawa et al. (2013a) all working on tomato recorded similar results and Dawa et al. (2013b) on sweet pepper.Also, ElNoemani et al. (2010), Abd El-Aal et al. (2011), and Marzouk et al. (2016) who showed that increase water quantity led to a significant increase of plant growth (plant height, number of branches and leaves /plant).

Table 1. Effect of irrigation quantity and fertilization treatments on Plant height, No. of. Leaves and No. of. Branches of tomato plants during the two seasons of study (2015-2016).

\begin{tabular}{|c|c|c|c|c|c|c|c|c|}
\hline \multirow{2}{*}{ Treatmen } & & & \multicolumn{2}{|c|}{ Plant height $(\mathrm{cm})$} & \multicolumn{2}{|c|}{ No. of. Leaves } & \multicolumn{2}{|c|}{ No. of. Branches } \\
\hline & & & $1^{\text {st }}$ & $2^{\text {nd }}$ & $1^{\text {st }}$ & $2^{\text {nd }}$ & $1^{\text {st }}$ & $2^{\text {nd }}$ \\
\hline \multirow{5}{*}{ 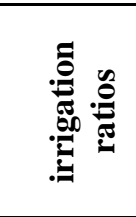 } & \multicolumn{2}{|c|}{$1456 \mathrm{~m}^{3} / \mathrm{fed}$} & 68.9 & 65.7 & 36.5 & 44.5 & 3.0 & 2.5 \\
\hline & \multicolumn{2}{|c|}{$2184 \mathrm{~m}^{3} /$ fed } & 91.1 & 77.1 & 53.9 & 61.4 & 3.4 & 4.0 \\
\hline & \multicolumn{2}{|c|}{$2912 \mathrm{~m}^{3} / \mathrm{fed}$} & 108.5 & 87.5 & 69.5 & 69.5 & 4.4 & 5.0 \\
\hline & \multicolumn{2}{|c|}{$3640 \mathrm{~m}^{3} /$ fed } & 93.2 & 76.1 & 55.2 & 69.5 & 3.5 & 3.3 \\
\hline & \multicolumn{2}{|l|}{ LSD } & 2.7 & 5.4 & 1.8 & 2.8 & 0.5 & 0.9 \\
\hline \multirow{5}{*}{ 包 } & \multicolumn{2}{|l|}{ Fert.1 } & 77.8 & 66.8 & 37.6 & 59.0 & 2.8 & 2.6 \\
\hline & \multicolumn{2}{|l|}{ Fert.2 } & 84.1 & 70.4 & 44.0 & 51.5 & 3.0 & 3.2 \\
\hline & \multicolumn{2}{|l|}{ Fert.3 } & 103.1 & 88.5 & 70.1 & 62.4 & 4.6 & 4.7 \\
\hline & \multicolumn{2}{|l|}{ Fert.4 } & 96.6 & 80.9 & 63.3 & 72.1 & 3.9 & 4.2 \\
\hline & \multicolumn{2}{|l|}{ LSD } & 2.1 & 2.2 & 1.9 & 2.3 & 0.4 & 0.4 \\
\hline \multirow{6}{*}{ : } & \multirow{4}{*}{1456} & Fert1 & 62.6 & 60.6 & 30.3 & 30.6 & 2.6 & 1.3 \\
\hline & & Fert2 & 68.0 & 59.6 & 33.6 & 31.0 & 2.3 & 2.3 \\
\hline & & Fert3 & 73.3 & 76.6 & $\begin{array}{l}42.0 \\
\end{array}$ & $\begin{array}{l}60.3 \\
\end{array}$ & 3.6 & 3.6 \\
\hline & & Fert4 & 71.6 & 66.0 & 40.3 & $\begin{array}{l}56.0 \\
\end{array}$ & 3.3 & 3.0 \\
\hline & \multirow{4}{*}{2184} & Fert1 & 71.0 & 63.0 & 28.0 & $\begin{array}{l}56.0 \\
\end{array}$ & 2.3 & 3.3 \\
\hline & & Fert2 & 87.6 & 71.6 & 47.3 & 59.6 & 3.0 & 3.6 \\
\hline \multirow{7}{*}{ Dే: } & & Fert3 & 106.0 & 88.3 & $\begin{array}{l}70.3 \\
\end{array}$ & $\begin{array}{l}58.0 \\
\end{array}$ & 4.6 & 4.6 \\
\hline & & Fert4 & 100.0 & 85.6 & 70.0 & 72.0 & 3.6 & 4.3 \\
\hline & \multirow{4}{*}{2912} & Fert1 & 101.0 & 76.0 & $\begin{array}{l}56.0 \\
\end{array}$ & $\begin{array}{l}69.0 \\
\end{array}$ & 3.6 & 3.6 \\
\hline & & Fert2 & 102.3 & 77.0 & 54.6 & 57.6 & 3.6 & 4.3 \\
\hline & & Fert3 & 118.3 & 103.0 & 90.3 & $\begin{array}{l}66.3 \\
\end{array}$ & 5.6 & 6.3 \\
\hline & & Fert4 & 112.3 & 94.3 & 77.0 & 85.3 & 4.6 & 5.6 \\
\hline & \multirow{4}{*}{3640} & Fert1 & 76.6 & 67.6 & \begin{tabular}{|l|}
36.3 \\
\end{tabular} & 80.6 & 2.6 & 2.3 \\
\hline \multirow{4}{*}{ 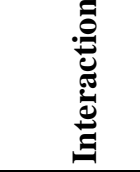 } & & Fert2 & 78.6 & 73.3 & 40.6 & 57.6 & 3.0 & 2.6 \\
\hline & & Fert3 & 115.0 & 86.0 & $\begin{array}{l}78.0 \\
\end{array}$ & 65.0 & 4.6 & 4.3 \\
\hline & & Fert4 & 102.6 & 77.6 & $\begin{array}{l}66.0 \\
\end{array}$ & 75.0 & 4.0 & 4.0 \\
\hline & LSD & & 4.3 & 4.5 & 3.8 & 4.6 & 0.9 & 0.9 \\
\hline
\end{tabular}


Table 2. fect of irrigation quantity and fertilization treatments on F w. leaves $(\mathrm{g}), \mathrm{F}$ w. branches $(\mathrm{g})$ and $\mathrm{F}$ w. plant $(\mathrm{g})$ of tomato plants during the two seasons of study (2015-2016).

\begin{tabular}{|c|c|c|c|c|c|c|c|c|}
\hline \multirow{2}{*}{\multicolumn{3}{|c|}{ Treatment }} & \multicolumn{2}{|c|}{ F w. leaves (g) } & \multicolumn{2}{|c|}{ F w. branches (g) } & \multicolumn{2}{|c|}{ F w. plant (g) } \\
\hline & & & $1^{\text {st }}$ & $2^{\text {nd }}$ & $1^{\text {st }}$ & $2^{\text {nd }}$ & $1^{\text {st }}$ & $2^{\text {nd }}$ \\
\hline \multirow{5}{*}{ 泀 } & \multicolumn{2}{|c|}{$1456 \mathrm{~m}^{3} /$ fed } & 160.13 & 204.00 & 105.29 & 124.00 & 265.42 & 328.00 \\
\hline & \multicolumn{2}{|c|}{$2184 \mathrm{~m}^{3} /$ fed } & 226.11 & 238.33 & 174.90 & 187.83 & 401.01 & 426.16 \\
\hline & \multicolumn{2}{|c|}{$2912 \mathrm{~m}^{3} /$ fed } & 293.017 & 383.75 & 198.25 & 228.83 & 491.27 & 612.58 \\
\hline & \multicolumn{2}{|c|}{$3640 \mathrm{~m}^{3} /$ fed } & 297.76 & 283.00 & 184.20 & 171.25 & 481.96 & 454.25 \\
\hline & \multicolumn{2}{|c|}{ LSD } & 6.64 & 4.06 & 10.34 & 7.42 & 12.29 & 8.93 \\
\hline \multirow{5}{*}{ 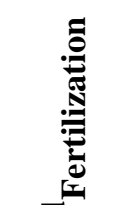 } & \multicolumn{2}{|l|}{ Fert.1 } & 179.60 & 190.33 & 117.07 & 152.66 & 296.68 & 343.00 \\
\hline & \multicolumn{2}{|l|}{ Fert.2 } & 216.03 & 232.50 & 140.97 & 168.25 & 357.01 & 400.75 \\
\hline & \multicolumn{2}{|l|}{ Fert.3 } & 317.66 & 374.08 & 215.25 & 208.50 & 532.92 & 582.58 \\
\hline & \multicolumn{2}{|l|}{ Fert.4 } & 263.72 & 312.16 & 189.34 & 182.50 & 453.06 & 494.66 \\
\hline & \multicolumn{2}{|l|}{ LSD } & 9.33 & 3.18 & 7.10 & 8.11 & 12.54 & 8.85 \\
\hline \multirow{3}{*}{$\stackrel{\Xi}{\Xi}$} & \multirow{3}{*}{1456} & Fert1 & 151.80 & 109.66 & 79.66 & 108.33 & 231.46 & 218.00 \\
\hline & & Fert2 & 156.30 & 144.66 & 91.76 & 120.00 & 248.06 & 264.66 \\
\hline & & Fert3 & 167.06 & 298.00 & 132.23 & 159.33 & 299.30 & 457.33 \\
\hline \multirow{5}{*}{ } & \multirow{5}{*}{2184} & Fert4 & 165.36 & 263.66 & 117.50 & 108.33 & 282.86 & 372.00 \\
\hline & & Fert1 & 168.06 & 187.00 & 86.03 & 170.00 & 254.10 & 357.00 \\
\hline & & Fert2 & 192.10 & 237.00 & 157.56 & 179.66 & 349.66 & 416.66 \\
\hline & & Fert3 & 293.50 & 284.66 & 230.66 & 214.33 & 524.16 & 499.00 \\
\hline & & Fert4 & 250.80 & 244.66 & 225.33 & 187.33 & 476.13 & 432.00 \\
\hline \multirow{4}{*}{ : } & \multirow{4}{*}{2912} & Fert1 & 174.80 & 236.33 & 140.93 & 158.33 & 315.73 & 394.66 \\
\hline & & Fert2 & 263.26 & 281.00 & 155.23 & 193.33 & 418.50 & 474.33 \\
\hline & & Fert3 & 395.33 & 581.00 & 281.76 & 328.00 & 677.10 & 909.00 \\
\hline & & Fert4 & 338.66 & 436.66 & 215.10 & 235.66 & 553.76 & 672.33 \\
\hline \multirow{5}{*}{ 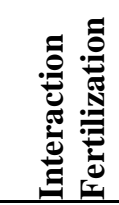 } & \multirow{4}{*}{3640} & Fert1 & 223.76 & 228.33 & 161.66 & 174.00 & 385.43 & 402.33 \\
\hline & & Fert2 & 252.47 & 267.33 & 159.33 & 180.00 & 411.80 & 447.33 \\
\hline & & Fert3 & 414.76 & 332.66 & 216.36 & 132.33 & 631.13 & 465.00 \\
\hline & & Fert4 & 300.06 & 303.66 & 199.43 & 198.66 & 499.50 & 502.33 \\
\hline & LSD & & 18.74 & 6.37 & 14.21 & 16.23 & 25.09 & 17.70 \\
\hline
\end{tabular}

4-2- Chemical composition of plant foliage.

Data recorded in Table (4) clear the effect of irrigation quantity and fertilization treatments as well as their interaction on chemical composition of tomato plant foliage gpressed as N,P and K percentage during 2015 and 2016 season of growth. 4-2-1- Effect of irrigation quantity.

Data at Table (4) show the effect of irrigation water amount (1456,2184, 2912 and $3640 \mathrm{~m}^{3} /$ fed.) on chemical composition of tomato there were a significant differences in all measured mineral constituents of plant foliage among the amounts used of irrigation water during both season of growth. Such data clear that increasing the quantity of irrigation water applied from 1456 up to 2912 $\mathrm{m}^{3} / \mathrm{fed}$. Led to increase in all measured mineral constituents of plant foliage. In this respect, the highest values in all determined macro elements were obtained in case of using $2912 \mathrm{~m}^{3} / \mathrm{fed}$. of irrigation water, followed by using $3640 \mathrm{~m}^{3} / \mathrm{fed}$. obtained results are true during both seasons of growth. Such enhancing effect of irrigation water amounts on mineral constituents with increasing the rate of irrigation water may be due to the increase in water and mineral constituents up take by plant roots and trans location to plant foliage. Which, causes the increasing of the concentration of such constituents in plant foliage tissues. Also, the higher mineral contents in case of using $2912 \mathrm{~m}^{3} / \mathrm{fed}$. Of irrigation water was connected with the higher vegetative growth compared with the other uses amounts of irrigation water (Tables 1,2 and 3). Obtained results are in agreement with those reported by Amer et al. (2002b), Sawan et al. (2002), Ismail (2004), ELTantawy and EL-Beik (2007), Ghassemi-Golezani and Mardfar (2008), El-Noemani et al. (2010), ElAal et al. (2011), Byan (2014), Silva et al. (2016), Marzouk et al. (2016), Farahmand, A. $\mathrm{R}$ et al.(2006) and Morais et al. (2017) who revealed that increasing the amount of irrigation water led to an increase in total yield and its attributes i.e., weight and numbers of pods / plant as well as early yield. 
Table 3. Effect of irrigation quantity and fertilization treatments on D w. leaves (g), D w. branches (g) and D w. plant $(\mathrm{g})$ of tomato plants during the two seasons of study (2015-2016).

\begin{tabular}{|c|c|c|c|c|c|c|c|c|}
\hline \multirow{2}{*}{\multicolumn{3}{|c|}{ Treatment }} & \multicolumn{2}{|c|}{ D w. leaves (g) } & \multicolumn{2}{|c|}{ D w. branches (g) } & \multicolumn{2}{|c|}{ D w. plant (g) } \\
\hline & & & $1^{\text {st }}$ & $2^{\text {nd }}$ & $\mathbf{1}^{\text {st }}$ & $2^{\text {nd }}$ & $1^{\text {st }}$ & $2^{\text {nd }}$ \\
\hline \multirow{5}{*}{ 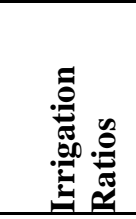 } & \multicolumn{2}{|c|}{$1456 \mathrm{~m}^{3} / \mathrm{fed}$} & 40.45 & 45.55 & 28.41 & 32.32 & 68.86 & 77.87 \\
\hline & \multicolumn{2}{|c|}{$2184 \mathrm{~m}^{3} /$ fed } & 63.07 & 62.59 & 40.90 & 53.02 & 103.97 & 115.61 \\
\hline & \multicolumn{2}{|c|}{$2912 \mathrm{~m}^{3} / \mathrm{fed}$} & 78.25 & 87.13 & 61.39 & 65.98 & 139.65 & 153.11 \\
\hline & \multicolumn{2}{|c|}{$3640 \mathrm{~m}^{3} /$ fed } & 70.38 & 70.15 & 51.50 & 55.28 & 121.89 & 125.35 \\
\hline & \multicolumn{2}{|l|}{ LSD } & 2.83 & 2.48 & 3.80 & 1.98 & 4.81 & 3.73 \\
\hline \multirow{5}{*}{. } & \multicolumn{2}{|l|}{ Fert.1 } & 37.76 & 44.38 & 28.57 & 36.21 & 66.34 & 80.52 \\
\hline & \multicolumn{2}{|l|}{ Fert.2 } & 53.35 & 58.43 & 38.87 & 43.18 & 92.23 & 101.66 \\
\hline & \multicolumn{2}{|l|}{ Fert.3 } & 101.45 & 97.17 & 65.75 & 73.84 & 167.20 & 171.00 \\
\hline & \multicolumn{2}{|l|}{ Fert.4 } & 59.59 & 65.47 & 49.00 & 53.30 & 108.60 & 118.76 \\
\hline & \multicolumn{2}{|l|}{ LSD } & 2.23 & 2.25 & 2.03 & 2.56 & 2.87 & 3.47 \\
\hline \multirow{17}{*}{ :气 } & \multirow{4}{*}{1456} & Fert1 & 25.80 & 17.40 & 17.33 & 17.20 & 43.13 & 34.60 \\
\hline & & Fert2 & 31.33 & 44.50 & 18.66 & 24.43 & 50.00 & 68.93 \\
\hline & & Fert3 & 61.66 & 64.03 & 50.00 & 55.23 & 111.66 & 119.27 \\
\hline & & Fert4 & 43.00 & 56.26 & 27.66 & 32.43 & 70.66 & 88.70 \\
\hline & \multirow{4}{*}{2184} & Fert1 & 50.26 & 50.30 & 9.33 & 36.53 & 59.60 & 86.83 \\
\hline & & Fert2 & 61.20 & 58.96 & 30.46 & 44.63 & 91.66 & 103.60 \\
\hline & & Fert3 & 78.33 & 78.73 & 70.93 & 75.53 & 149.27 & 154.26 \\
\hline & & Fert4 & 62.50 & 62.36 & 52.86 & 55.40 & 115.36 & 117.76 \\
\hline & \multirow{4}{*}{2912} & Fert1 & 38.00 & 48.93 & 42.76 & 48.80 & 80.76 & 97.73 \\
\hline & & Fert2 & 65.00 & 65.40 & 56.00 & 57.30 & 121.00 & 122.70 \\
\hline & & Fert3 & 140.43 & 159.87 & 82.00 & 90.06 & 222.43 & 249.93 \\
\hline & & Fert4 & 69.60 & 74.33 & 64.80 & 67.76 & 134.40 & 142.10 \\
\hline & \multirow{4}{*}{3640} & Fert1 & 37.00 & 60.60 & 44.86 & 42.33 & 81.86 & 102.93 \\
\hline & & Fert2 & 55.90 & 65.06 & 50.36 & 46.36 & 106.26 & 111.43 \\
\hline & & Fert3 & 125.36 & 86.03 & 60.10 & 74.53 & 185.46 & 160.57 \\
\hline & & Fert4 & 63.26 & 68.90 & 50.70 & 57.60 & 113.96 & 126.50 \\
\hline & \multicolumn{2}{|l|}{ LSD } & 4.46 & 4.50 & 4.07 & 5.12 & 5.75 & 6.95 \\
\hline
\end{tabular}

Fert $1=25 \%(\mathrm{NPK})+$ Organic

Fert $2=50 \%(\mathrm{NPK})+$ Organic

\section{4-2-2- Effect of fertilization treatments.}

Data illustrated in Table (4) show that there were significant differences among the tested fertilizer treatments in all assayed mineral composition of plant foliage expressed as $\mathrm{N} \%, \mathrm{P} \%$ and $\mathrm{K} \%$ during both seasons of study. In this concern, application of $100 \%$ of recommended doses of NPK mineral fertilizers reflected the highest plant foliage content of N,P and K content compared with the other used fertilizers treatments, followed by using $75 \%$ from the recommended doses of NPK mineral fertilizers+ organic manure gave the lowest values of the all the formations chemical composition traits of plant foliage obtained results may be due to the synergistic effect of mineral NPK fertilizers and organic manure in increasing the absorption of NPK elements by plant roots. Such enhancing effect of mineral nitrogen and chicken manure on produced yield was noticed by Abd El- Rahman (2003), El-Robae (2003), Patial et al. (2004), El-Mansi et al. (2004), Shuayb (2004), El- Beheidi et al. (2006), Thimma (2006), Ewulo et al. (2008), Law-Ogbomo and Egharevba (2008), Olaniyi and Ajibola (2008), Baddour (2010) Hamden and Fadni (2010),
Fert3 $=75 \%(\mathrm{NPK})+$ Organic

Fert $4=100 \%$ (NPK)
Muhammed et al. (2011) and Agyeman et al. (2014) all working on tomato.

\section{4-2-3- Effect of the interaction.}

As for the interaction effect, data at Table (4) showed that there were significant differences between the interaction treatments between irrigation water quantity and fertilization treatments in all measures mineral composition of plant foliage during both seasons of growth. In this respect application of $2912 \mathrm{~m}^{3} /$ fed. Of irrigation water combined with $100 \%$ of the recodes doses of NPK mineral fertilizers only gave the highest plant foliage content of NPK compared with the other used interaction treatments, followed by using $3640 \mathrm{~m}^{3} / \mathrm{fed}$. Irrigation water with the same level of fertilization .on the opisite side, the interaction treatments between $1456 \mathrm{~m}^{3} / \mathrm{fed}$. Irrigation water the lowest quantity and $25 \%$ from the recommended doses of NPK mineral fertilizers +organic manure reflected the lowest values from the formations chemical composition of plant foliage traits, followed by the interaction treatment between applied $2184 \mathrm{~m}^{3} / \mathrm{fed}$. irrigation water the same fertilizer treatment. 
Table 4. Effect of irrigation quantity and fertilization treatments on Number fruits, Average fruit weight (g), Fruit /plant (kg)and yield /fed (ton)of tomato plants during the two seasons of study (2015-2016).

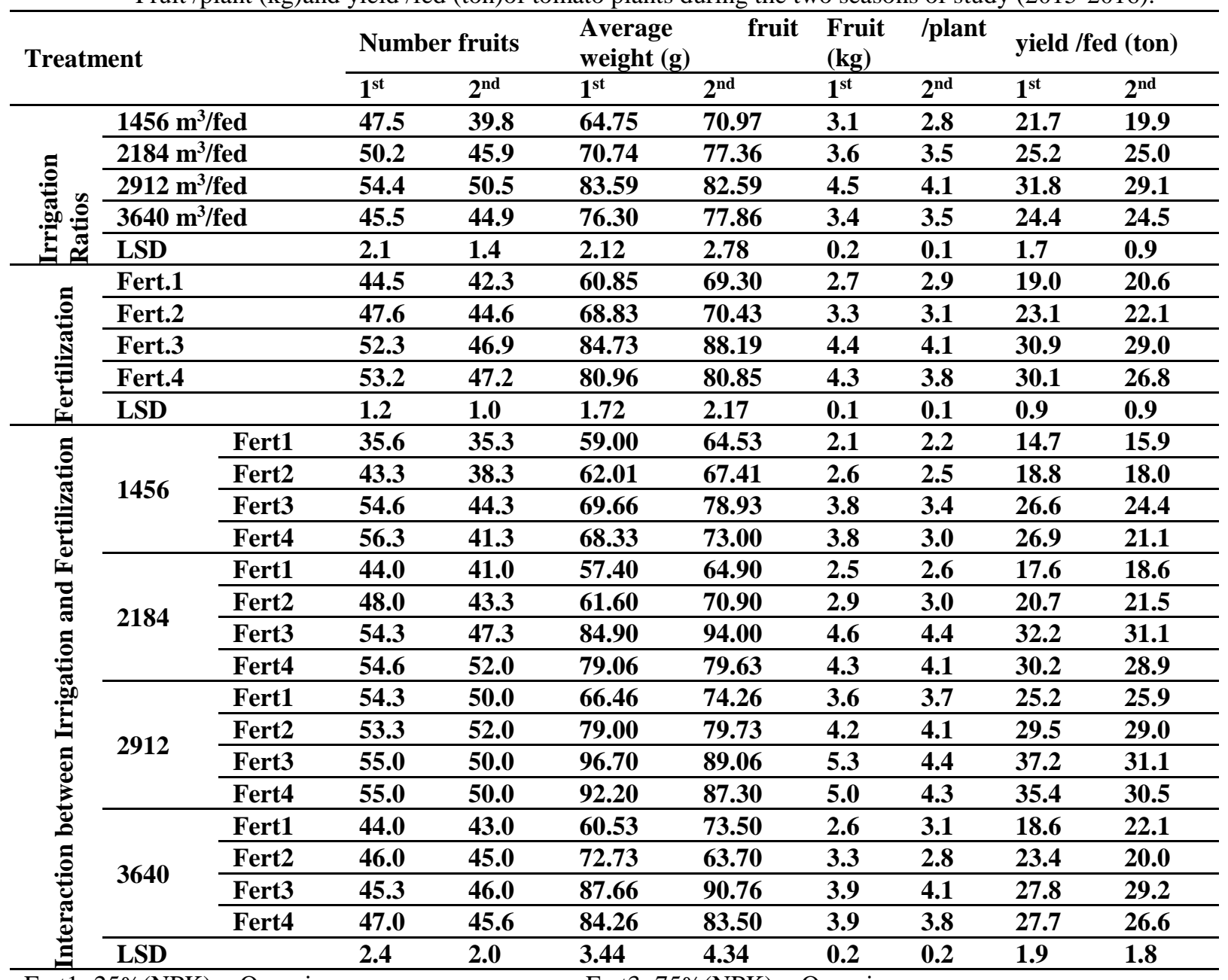

Fert1 $=25 \%(\mathrm{NPK})+$ Organic

Fert $2=50 \%(\mathrm{NPK})+$ Organic

\section{4-3-Fruit yield and its components.}

Obtained data in (Table 5) show the effect of water irrigation quantity and fertilizers treatments as well as their interaction on fruit yield and its components atpressed as number of fruits per plants average fruit weight, fruit yield per plant and total fruit yield per fed.

\section{4-3-1- Effect of irrigation quantity.}

Data on the effect of irrigation water quantity on total fruit yield and its components are presented in table (4), such data show that there were significant differences in total produced fruit yield and its components, i.e., number of fruits per plant, average fruit weight, plant fruit yield and total fruit yield per fed. among the used irrigation water quantity during both seasons of study. such data reveal that there were progressive and consistent increments in total fruit yield and its components with increasing the amount of irrigation water from $1456 \mathrm{~m}^{3} /$ fed. Upto $2912 \mathrm{~m}^{3} /$ fed. And decreased with increasing the amount of irrigation water up to $3640 \mathrm{~m}^{3} / \mathrm{fed}$. during both seasons of this study. In this couarn, irrigated
Fert $3=75 \%(\mathrm{NPK})+$ Organic

Fert $4=100 \%$ (NPK) tomato plants with $2912 \mathrm{~m}^{3} /$ fed produced the highest total fruit yield and its components compared with other used irrigation water quantity treatments on the other hand, the lowest values in total fruit yield and its components were recorded by application of $1456 \mathrm{~m}^{3} /$ fed of water irrigation in both seasons of growth. Such increases in total fruit yield are related with increasing in number of fruits per plant and plant fruit yield as well as increasing in average fruit weight. Also, such increments in total fruit yield and its components due to increasing the quantity of irrigation water applied are connected with the enhancing effect of quantity of irrigation water on vegetative growth traits of plants (Tables, 1,2 and 3) which in turn effect on the yielding ability of plants. The increase in minerals content might be attributed to increase in dry matter accumulation with increasing water levels was reported

by Merghany (1999) on snap been, Nour (1999) on pea and Sawan et al. (2001) on sugar pea.

\section{4-3-2- Effect of fertilization treatments.}


Data presented in Table (5) show clearly that there were significant differences in all measured fruit yield its components parameters among the studied fertilizer treatments. In this concern, the highest values in average fruit weight, plant fruit yield and total fruit yield per fed. Were obtained as a result of fertilization with to $75 \%$ from the recommended doses of NPK mineral fertilizers plus $25 \%$ organic manure followed by the treatment treated with $100 \%$ from the recommended doses of NPK mineral fertilizers. Obtained results are true during 2015 and 2016 seasons of study. Meanwhile, the highest number of fruit per plant were obtained from fertilizing tomato plants with $100 \%$ from the recommended doses of NPK mineral fertilizers. this is true during both seasons of growth (Table,5). The positive effect of using $75 \%$ from the recommended doses NPK mineral fertilizers combined with $25 \%$ organic manure on fruit yield and its components may be due to the promotive effect of such treatment on vegetative growth traits (Tables,1,2 and 3) which affect consequently on fruit yield production. Obtained results are similar to those reported by Abo-El- Defan (1990), Fattahallah (1992a), Moursey, et al. (2001), Darwish (2002), El-Naggar (2004), Ewulo et al. (2008) and Ayeni et al (2010) all working on tomato reported that fertilizing tomato plants with organic manure at different rates enhanced N,P and K contents of plant foliage. Also, El-Beheidi et al. (1991), Merghany (1997), Barakat and Gabr (1998), Mohsen (2006) and Dawa et al. (2013) reported similar results in case of using mineral nitrogen fertilizer.

Table 5. Effect of irrigation quantity and fertilization treatments on N (\%), P (\%), K (\%) and Protein (\%) of tomato plants during the two seasons of study (2015-2016).

\begin{tabular}{|c|c|c|c|c|c|c|c|c|c|c|}
\hline \multirow{2}{*}{ Treatmen } & & & \multicolumn{2}{|c|}{$\mathrm{N}(\%)$} & \multicolumn{2}{|c|}{$\mathbf{P}(\%)$} & \multicolumn{2}{|c|}{ K (\%) } & \multicolumn{2}{|c|}{ Protein (\%) } \\
\hline & & & $1^{\text {st }}$ & $2^{\text {nd }}$ & $1^{\text {st }}$ & $2^{\text {nd }}$ & 1 $^{\text {st }}$ & $2^{\text {nd }}$ & $1^{\text {st }}$ & $2^{\text {nd }}$ \\
\hline \multirow{5}{*}{ 氙 } & \multicolumn{2}{|c|}{$1456 \mathrm{~m}^{3} / \mathrm{fed}$} & 1.23 & 1.25 & 0.27 & 0.27 & 0.62 & 0.63 & 7.72 & 7.85 \\
\hline & \multicolumn{2}{|c|}{$2184 \mathrm{~m}^{3} /$ fed } & 1.25 & 1.32 & 0.32 & 0.31 & 0.70 & 0.69 & 7.83 & 8.25 \\
\hline & \multicolumn{2}{|c|}{$2912 \mathrm{~m}^{3} / \mathrm{fed}$} & 1.46 & 1.46 & 0.33 & 0.32 & 0.79 & 0.74 & 9.15 & 9.13 \\
\hline & \multicolumn{2}{|c|}{$3640 \mathrm{~m}^{3} / \mathrm{fed}$} & 1.44 & 1.43 & 0.32 & 0.32 & 0.78 & 0.72 & 9.00 & 8.99 \\
\hline & \multicolumn{2}{|l|}{ LSD } & 0.03 & 0.01 & 0.01 & 0.01 & 0.01 & 0.03 & 0.21 & 0.12 \\
\hline \multirow{5}{*}{ } & \multicolumn{2}{|l|}{ Fert.1 } & 1.21 & 1.22 & 0.30 & 0.29 & 0.58 & 0.58 & 7.58 & 7.63 \\
\hline & \multicolumn{2}{|l|}{ Fert.2 } & 1.26 & 1.30 & 0.31 & 0.30 & 0.70 & 0.67 & 7.91 & 8.13 \\
\hline & \multicolumn{2}{|l|}{ Fert.3 } & 1.42 & 1.44 & 0.32 & 0.32 & 0.77 & 0.72 & 8.92 & 9.04 \\
\hline & \multicolumn{2}{|l|}{ Fert.4 } & 1.48 & 1.50 & 0.32 & 0.32 & 0.84 & 0.81 & 9.28 & 9.43 \\
\hline & \multicolumn{2}{|l|}{ LSD } & 0.02 & 0.02 & 0.01 & 0.01 & 0.02 & 0.01 & 0.15 & 0.14 \\
\hline \multirow{5}{*}{ 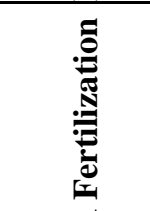 } & \multirow{4}{*}{1456} & Fert1 & 1.18 & 1.21 & 0.26 & 0.25 & 0.52 & 0.53 & 7.39 & 7.56 \\
\hline & & Fert2 & 1.21 & 1.23 & 0.26 & 0.26 & 0.63 & 0.63 & 7.60 & 7.77 \\
\hline & & Fert3 & 1.26 & 1.27 & 0.28 & $\begin{array}{l}0.28 \\
\end{array}$ & 0.66 & 0.66 & 7.89 & 7.97 \\
\hline & & Fert4 & 1.28 & 1.30 & 0.29 & $\begin{array}{l}0.28 \\
\end{array}$ & 0.68 & $\begin{array}{l}0.73 \\
\end{array}$ & 8.00 & 8.12 \\
\hline & \multirow{4}{*}{2184} & Fert1 & 1.19 & 1.22 & 0.31 & 0.29 & 0.55 & 0.57 & 7.47 & 7.64 \\
\hline \multirow{5}{*}{ 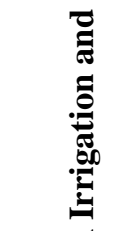 } & & Fert2 & 1.21 & 1.28 & 0.32 & 0.31 & 0.67 & 0.63 & 7.56 & 8.00 \\
\hline & & Fert3 & 1.27 & 1.34 & 0.33 & $\begin{array}{l}0.33 \\
\end{array}$ & 0.75 & 0.73 & 7.97 & 8.41 \\
\hline & & Fert4 & 1.33 & 1.43 & $\begin{array}{l}\mathbf{0 . 3 3} \\
\end{array}$ & \begin{tabular}{|l|l|}
0.33 \\
\end{tabular} & 0.83 & $\begin{array}{l}\mathbf{0 . 8 2} \\
\end{array}$ & 8.31 & 8.95 \\
\hline & \multirow{4}{*}{2912} & Fert1 & 1.24 & 1.23 & $\begin{array}{l}0.31 \\
\end{array}$ & $\begin{array}{l}0.31 \\
\end{array}$ & 0.64 & 0.63 & 7.77 & 7.72 \\
\hline & & Fert2 & 1.33 & 1.35 & 0.32 & 0.32 & 0.75 & 0.72 & 8.33 & 8.43 \\
\hline \multirow{7}{*}{ 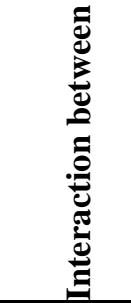 } & & Fert3 & 1.59 & 1.59 & 0.34 & $\mathbf{0 . 3 3}$ & 0.86 & 0.76 & 9.97 & 9.95 \\
\hline & & Fert4 & 1.68 & 1.66 & 0.34 & 0.34 & 0.94 & 0.85 & 10.52 & 10.41 \\
\hline & \multirow{4}{*}{3640} & Fert1 & 1.23 & 1.21 & 0.31 & $\begin{array}{l}0.31 \\
\end{array}$ & 0.62 & 0.61 & $\mathbf{7 . 7 0}$ & 7.58 \\
\hline & & Fert2 & 1.30 & 1.33 & 0.32 & 0.32 & 0.74 & 0.71 & 8.16 & 8.33 \\
\hline & & Fert3 & 1.57 & 1.57 & 0.34 & 0.33 & 0.83 & 0.74 & 9.85 & 9.83 \\
\hline & & Fert4 & 1.64 & 1.63 & 0.34 & 0.34 & 0.92 & 0.82 & 10.27 & 10.22 \\
\hline & \multicolumn{2}{|l|}{ LSD } & 0.05 & 0.05 & 0.01 & 0.01 & 0.05 & 0.01 & $\begin{array}{l}0.31 \\
\end{array}$ & 0.28 \\
\hline \multicolumn{3}{|c|}{$\begin{array}{l}\text { Fert } 1=25 \%(\mathrm{NPK})+\text { Organic } \\
\text { Fert } 2=50 \%(\mathrm{NPK})+\text { Organic }\end{array}$} & & & $\begin{array}{l}5 \%(\mathrm{~N} \\
100 \%\end{array}$ & Or & & & & \\
\hline
\end{tabular}

\section{4-3-3- Effect of the interaction.}

With regard to the effect of the interaction between the amount of irrigation water and fertilization treatments, data illustrated in Table,5 clear that the total fruit yield per plant and feddan as well as number of fruits per plant and average fruit weight were significantly affected. In this concern, the highest fruit yield per plant and feddan were obtained from the interaction treatment between irrigation tomato plants with $2912 \mathrm{~m}^{3} / \mathrm{fed}$. irrigation water and fertilized with $75 \%$ from the recommended doses of NPK mineral fertilizers plus $25 \%$ organic manure. 
These results were true during both seasons growth. Moreover the highest average fruit weight were obtained from the same previously mentioned interaction treatment during the first season (2015), meanwhile during second one were obtained from the interaction treatment between irrigation with $2184 \mathrm{~m}^{3} /$ feddan and fertilization the plants with $75 \%$ from the recommended doses of NPK mineral fertilizers plus $25 \%$ organic manure. where as the highest number of fruits per plant in the first season of growth were obtained from irrigated tomato plants with $1456 \mathrm{~m}$ of irrigation water and fertilized with $100 \%$ from the recommended doses of NPK mineral fertilizer, while in the second season it was obtained from irrigated tomato plants with $100 \%$ from the recommended doses of NPK mineral fertilizers.

\section{4-4- N, P and K uptake.}

Data illustrated in Table (6) clear the effect of irrigation quantity and fertilization treatments as well as their interaction on nitrogen, phosphorus and potassium uptake in tomato plant foliage during the two seasons of study.

4-4-1- Effect of irrigation quantity.
With regard to the effect of irrigation rates on $\mathrm{N}, \mathrm{P}, \mathrm{K}$ uptake of plant foliage, it is clear from the recorded data in Table (6) that increasing quantity of irrigation water from $1456 \mathrm{~m}^{3} / \mathrm{fed} \mathrm{up} \mathrm{to} 2912 \mathrm{~m}^{3} / \mathrm{fed}$ significant increased the uptake of nitrogen , phosphorus and potassium in plant foliage. These results were true during 2015 and 2016 seasons of study. The highest values of NPK uptake by plant rools were obtained from tomato plants irrigated with $2912 \mathrm{~m}^{3} /$ fed. followed by $3640 \mathrm{~m}$.on the other hand the lowest values of NPK uptake were obtained when irrigated plants with the lowest value of irrigation water $\left(1456 \mathrm{~m}^{3} / \mathrm{fed}\right)$.the increases of NPK uptake in plant foliage as a result of increasing the irrigation water amount may be due to the increasing of absorbed and trans located water and macro elements to the various plant foliage parts, which in turn increased such amounts of macro-elements in different cells of plant partes. Also, such increment in all estimates macro-elements uptake was connected with the increase in vegetative growth parameters (Tables, 1, 2 and 3) as a result of increasing the quantity irrigation water application.

Table 6. Effect of irrigation quantity and fertilization treatments on $\mathrm{n}$ uptake, $\mathrm{p}$ uptake and $\mathrm{k}$ uptake of tomato plants during the two seasons of study (2015-2016).

\begin{tabular}{|c|c|c|c|c|c|c|c|c|}
\hline \multirow{2}{*}{\multicolumn{3}{|c|}{ Treatment }} & \multicolumn{2}{|c|}{ n uptake } & \multicolumn{2}{|c|}{ p uptake } & \multicolumn{2}{|c|}{ k uptake } \\
\hline & & & $1^{\text {st }}$ & $2^{\text {nd }}$ & $1^{\text {st }}$ & $2^{\text {nd }}$ & $1^{\text {st }}$ & $2^{\text {nd }}$ \\
\hline \multirow{5}{*}{ 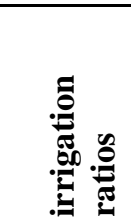 } & \multicolumn{2}{|c|}{$1456 \mathrm{~m}^{3} /$ fed } & 858.6 & 987.9 & 192.9 & 215.8 & 442.8 & 514.4 \\
\hline & \multicolumn{2}{|c|}{$2184 \mathrm{~m}^{3} /$ fed } & 1315.6 & 1538.7 & 344.4 & 373.1 & 759.2 & 813.1 \\
\hline & \multicolumn{2}{|c|}{$2912 \mathrm{~m}^{3} /$ fed } & 2109.1 & 2303.5 & 467.1 & 508.0 & 1151.7 & 1156.2 \\
\hline & \multicolumn{2}{|c|}{$3640 \mathrm{~m}^{3} /$ fed } & 1798.3 & 1832.5 & 404.3 & 412.7 & 972.7 & 915.5 \\
\hline & \multicolumn{2}{|c|}{ LSD } & 107.5 & 52.3 & 16.9 & 12.3 & 64.0 & 29.8 \\
\hline \multirow{5}{*}{ 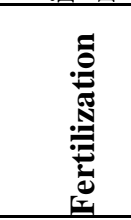 } & \multicolumn{2}{|l|}{ Fert.1 } & 809.7 & 984.5 & 202.0 & 243.0 & 397.0 & 482.5 \\
\hline & \multicolumn{2}{|l|}{ Fert.2 } & 1179.7 & 1330.9 & 292.2 & 316.2 & 658.9 & 693.5 \\
\hline & \multicolumn{2}{|l|}{ Fert.3 } & 2447.5 & 2527.5 & 552.8 & 558.4 & 1331.0 & 1252.5 \\
\hline & \multicolumn{2}{|l|}{ Fert.4 } & 1644.6 & 1819.5 & 361.6 & 392.0 & 939.5 & 970.7 \\
\hline & \multicolumn{2}{|l|}{ LSD } & 43.2 & 53.1 & 9.7 & 10.91 & 37.0 & 35.6 \\
\hline \multirow{6}{*}{ : } & \multirow{4}{*}{1456} & Fert1 & 510.4 & 418.5 & 114.7 & 89.5 & 227.1 & 185.0 \\
\hline & & Fert2 & 608.4 & 856.9 & 133.5 & 183.0 & 318.2 & 433.5 \\
\hline & & Fert3 & 1410.9 & 1522.7 & 316.7 & 335.9 & 740.6 & 791.4 \\
\hline & & Fert4 & 904.5 & 1153.4 & 206.8 & 254.8 & 485.2 & 647.6 \\
\hline & \multirow{4}{*}{2184} & Fert1 & 713.2 & 1062.1 & 185.7 & 254.3 & 328.1 & 494.9 \\
\hline & & Fert2 & 1109.1 & 1325.9 & 297.3 & 322.8 & 617.1 & 653.2 \\
\hline \multirow{4}{*}{ } & & Fert3 & 1905.9 & 2078.6 & 503.5 & 517.8 & 1129.5 & 1130.7 \\
\hline & & Fert4 & 1534.2 & \begin{tabular}{|l|}
1688.1 \\
\end{tabular} & 391.0 & 397.2 & 962.0 & 973.4 \\
\hline & \multirow{4}{*}{2912} & Fert1 & 1005.4 & 1208.6 & 253.3 & 306.8 & 522.6 & 615.8 \\
\hline & & Fert2 & 1613.3 & 1655.6 & 393.6 & 398.4 & 907.5 & 892.0 \\
\hline \multirow{7}{*}{ 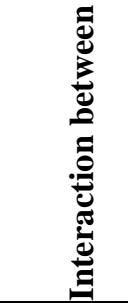 } & & Fert3 & 3550.9 & 3982.2 & 760.0 & 841.3 & 1914.2 & 1899.4 \\
\hline & & Fert4 & 2266.8 & 2367.6 & 461.4 & 485.4 & 1262.6 & $\mathbf{1 2 1 7 . 8}$ \\
\hline & \multirow{4}{*}{3640} & Fert1 & 1009.6 & 1249.1 & 254.3 & 321.5 & 510.3 & 634.3 \\
\hline & & Fert2 & 1388.1 & 1485.4 & 344.5 & 360.6 & 792.9 & 795.2 \\
\hline & & Fert3 & 2922.3 & 2526.4 & 631.2 & 538.4 & 1539.7 & 1188.4 \\
\hline & & Fert4 & 1873.0 & 2069.0 & 387.1 & 430.4 & 1048.1 & 1044.0 \\
\hline & \multicolumn{2}{|l|}{ LSD } & 86.5 & 106.2 & 19.5 & 21.8 & 74.0 & 71.2 \\
\hline \multicolumn{3}{|c|}{$\begin{array}{c}\text { Fert } 1=25 \%(\mathrm{NPK})+\text { Organic } \\
\text { Fert } 2=50 \%(\mathrm{NPK})+\text { Organic }\end{array}$} & & $\begin{array}{r}\text { Fert3 } 3 \\
\text { Fer }\end{array}$ & $\begin{array}{l}\%(\mathrm{NP} \\
00 \% \\
\end{array}$ & anic & & \\
\hline
\end{tabular}


4-4-2- Effect of fertilization treatments.

Referring to the effect of fertilization treatments on the uptake of N,P and $\mathrm{K}$ by plant roots , the some data in Table (5) show clearly that the uptake of such NPK elements was significantly differed as a result of the application of fertilization treatments as mineral form or organic manure. In this respect the highest nitrogen, phosphorus and potassium uptake was connected with using $75 \%$ form the recommended doses of NPK mineral fertilizers + organic manure, followed by application of $100 \%$ from the recommended doses of NPK mineral fertilizers only. On the other hand the lowest values of NPK uptake by plant roots were obtained when fertilizing tomato plants with $25 \%$ from the recommended doses of NPK mineral fertilizers+ organic manure. Such increments in uptake of all estimated macro-elements were connected with the increase in vegetative growth traits (Tables,1,2 and 3 ) as a result of application fertilization treatments.

\section{4-4-3- Effect of the interaction.}

Data mentioned in Table (6) show that there were a significant effects on NPK uptake by plant roots due to the interaction between the irrigation water quantity and the used fertilization treatments. In the regard, application $2912 \mathrm{~m}^{3} / \mathrm{fed}$. of irrigation water with fertilizing plants with $75 \%$ from the recommended doses of NPK mineral fertilizers+ organic manure reflected the highest values of $\mathrm{N}, \mathrm{P}$ and $\mathrm{K}$ uptake by plant roots during both season of study than the other tested interaction treatments , followed by the interaction treatment between 3640 $\mathrm{m}^{3} / \mathrm{fed}$. of irrigation water plus the same mentioned fertilizers treatment. On the other hand, the lowest values of NPK uptake by plant roots were obtained from the interaction treatment between $1456 \mathrm{~m}^{3} / \mathrm{fed}$. of water irrigation with $25 \%$ from the recommended doses of NPK mineral fertilizer + organic manure, followed the same irrigation level $\left(1456 \mathrm{~m}^{3} / \mathrm{fed}\right.$. irrigation water) $+50 \%$ from the recommended doses of NPK mineral fertilizers + organic manure.

\section{4-4-Tss, Ascorbic acid and Vit.c.}

Data illustrated in Table (7) clear the effect of irrigation quantity and fertilization treatments as well as their interaction on nitrogen, phosphorus and potassium uptake in tomato plant foliage during the two seasons of study.

\section{4-4-1- Effect of irrigation quantity.}

With regard to the effect of irrigation rates on Tss, Ascorbic acid and Vit.c of fruits, it is clear from the recorded data in Table (7) that increasing quantity of irrigation water from $1456 \mathrm{~m}^{3} /$ fed up to $2912 \mathrm{~m}^{3} / \mathrm{fed}$ significant increased the uptake of nitrogen , phosphorus and potassium in plant foliage. These results were true during 2015 and 2016 seasons of study.

The highest values of Tss, Ascorbic acid and Vit.c by plant rools were obtained from tomato plants irrigated with $2912 \mathrm{~m}^{3} / \mathrm{fed}$. followed by $3640 \mathrm{~m}$.on the other hand the lowest values of Tss, Ascorbic acid and Vit.c were obtained when irrigated plants with the lowest value of irrigation water (1456 $\mathrm{m}^{3} /$ fed).the increases of Tss, Ascorbic acid and Vit.c in plant foliage as a result of increasing the irrigation water amount may be due to the increasing of absorbed and trans located water and macro elements to the various plant foliage parts, which in turn increased such amounts of macro-elements in different cells of plant partes.

\section{4-4-2- Effect of fertilization treatments.}

Referring to the effect of fertilization treatments on the Tss, Ascorbic acid and Vit.c by plant roots, the some data in Table (7) show clearly that the uptake of such NPK elements was significantly differed as a result of the application of fertilization treatments as mineral form or organic manure. In this respect the highest nitrogen, phosphorus and potassium uptake was connected with using $75 \%$ form the recommended doses of NPK mineral fertilizers + organic manure, followed by application of $100 \%$ from the recommended doses of NPK mineral fertilizers only. On the other hand the lowest values of Tss, Ascorbic acid and Vit.c by plant roots were obtained when fertilizing tomato plants with $25 \%$ from the recommended doses of NPK mineral fertilizers+ organic manure.

\section{4-4-3- Effect of the interaction.}

Data mentioned in Table (7) show that there were a significant effects on Tss, Ascorbic acid and Vit.c by plant roots due to the interaction between the irrigation water quantity and the used fertilization treatments. In the regard, application $2912 \mathrm{~m}^{3} / \mathrm{fed}$. of irrigation water with fertilizing plants with $75 \%$ from the recommended doses of NPK mineral fertilizers+ organic manure reflected the highest values of $\mathrm{N}, \mathrm{P}$ and $\mathrm{K}$ uptake by plant roots during both season of study than the other tested interaction treatments , followed by the interaction treatment between 3640 $\mathrm{m}^{3} /$ fed. of irrigation water plus the same mentioned fertilizers treatment. On the other hand, the lowest values of Tss, Ascorbic acid and Vit.c by plant roots were obtained from the interaction treatment between $1456 \mathrm{~m}^{3} / \mathrm{fed}$. of water irrigation with $25 \%$ from the recommended doses of NPK mineral fertilizer + organic manure, followed the same irrigation level $\left(1456 \mathrm{~m}^{3} / \mathrm{fed}\right.$. irrigation water $)+50 \%$ from the recommended doses of NPK mineral fertilizers + organic manure. Such increase in TSS, ascorbic acid and total acidity may be due to the decreasing in moisture content of fruit and the presences of other nutrient elements affecting on the assimilation of ascorbic acid and total acicity contents. In this connection Khalil (1982), Soares et al.(1985), Midan et al. (1986), Hasegawa (1989), Fattahallah (1992b), El-Gizawy et al. (1993), Elkner and 
Rumpel (1995), Merghany (1997), Abd-Allah et al. (2001), Moursey et al. (2001), Abd El- Rahman (2003), Akande and Adediran (2004), El-Mansi et al. (2004), El-Naggar (2004), Shuayb (2004), Heeb et al. (2006), Mohsen (2006), Shukla et al. (2006), Ewulo et al. (2008), Baddour (2010) and Kandil and Gad (2010) all working on tomato and Shehata (1992) and Ademoyegun et al. (2011) working on pepper reported that using organic fertilizer combined with mineral nitrogen has ppositive effect on fruit TSS, ascorbic acid and fruit titrable acidity content.

Table 7. Effect of irrigation quantity and fertilization treatments on TSS (\%), Acidity (\%) and Vit.C (mg/100 ml Juice) of tomato plants during the two seasons of study (2015-2016).

\begin{tabular}{|c|c|c|c|c|c|c|c|c|}
\hline \multirow{2}{*}{\multicolumn{3}{|c|}{ Treatment }} & \multicolumn{2}{|c|}{ TSS (\%) } & \multicolumn{2}{|c|}{ Acidity (\%) } & \multicolumn{2}{|c|}{ Vit.C(mg/100 ml Juice) } \\
\hline & & & $1^{\text {st }}$ & $2^{\text {nd }}$ & $1^{\text {st }}$ & $2^{\text {nd }}$ & $1^{\text {st }}$ & $2^{\text {nd }}$ \\
\hline \multirow{5}{*}{ 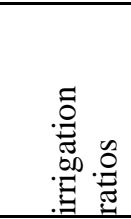 } & \multicolumn{2}{|c|}{$1456 \mathrm{~m}^{3} /$ fed } & 4.85 & 4.89 & 0.88 & 0.87 & 18.33 & 18.65 \\
\hline & \multicolumn{2}{|c|}{$2184 \mathrm{~m}^{3} /$ fed } & 4.50 & 4.59 & 0.77 & 0.74 & 19.96 & 20.76 \\
\hline & \multicolumn{2}{|c|}{$2912 \mathrm{~m}^{3} / \mathrm{fed}$} & 4.25 & 4.38 & 0.70 & 0.69 & 20.92 & 21.89 \\
\hline & \multicolumn{2}{|c|}{$3640 \mathrm{~m}^{3} /$ fed } & 3.93 & 3.99 & 0.65 & 0.65 & 18.62 & 19.49 \\
\hline & \multicolumn{2}{|l|}{ LSD } & 0.18 & 0.13 & 0.03 & 0.04 & 00.61 & 00.68 \\
\hline \multirow{5}{*}{ 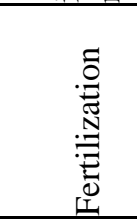 } & \multicolumn{2}{|c|}{$25 \%+$ org } & 3.99 & 4.04 & 0.63 & 0.60 & 17.18 & 17.97 \\
\hline & \multicolumn{2}{|c|}{$50 \%+$ org } & 4.21 & 4.22 & 0.73 & 0.69 & 19.37 & 20.20 \\
\hline & \multicolumn{2}{|c|}{$75 \%+$ org } & 4.75 & 4.99 & 0.87 & 0.82 & 21.64 & 22.85 \\
\hline & \multicolumn{2}{|l|}{$100 \%$} & 4.59 & 4.61 & 0.78 & 0.83 & 19.64 & 19.77 \\
\hline & \multicolumn{2}{|l|}{ LSD } & 0.28 & 0.11 & $\mathbf{0 . 0 3}$ & $\mathbf{0 . 0 3}$ & 00.36 & 00.34 \\
\hline \multirow{6}{*}{ 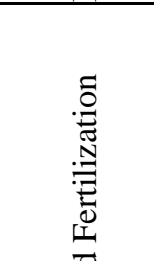 } & \multirow{4}{*}{1456} & Fert1 & 4.24 & 4.30 & 0.76 & 0.74 & 16.76 & 17.06 \\
\hline & & Fert2 & 4.57 & 4.64 & 0.82 & 0.80 & 17.95 & 18.90 \\
\hline & & Fert3 & 5.66 & 5.65 & 1.00 & 0.95 & 19.73 & 19.78 \\
\hline & & Fert4 & 4.94 & 4.99 & 0.95 & 0.99 & 18.88 & 18.86 \\
\hline & \multirow{4}{*}{2184} & Fert1 & 4.01 & 4.15 & 0.68 & 0.60 & 17.38 & 18.47 \\
\hline & & Fert2 & $\begin{array}{l}4.39 \\
\end{array}$ & 4.26 & $\begin{array}{l}0.78 \\
\end{array}$ & $\begin{array}{l}0.70 \\
\end{array}$ & 19.99 & 20.76 \\
\hline \multirow{5}{*}{ 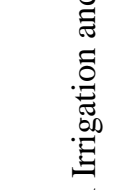 } & & Fert3 & 4.78 & 5.29 & 0.89 & 0.85 & 22.50 & 23.49 \\
\hline & & Fert4 & 4.83 & 4.64 & 0.74 & 0.81 & 19.98 & 20.33 \\
\hline & \multirow{4}{*}{2912} & Fert1 & 3.91 & 3.81 & 0.58 & 0.55 & 17.70 & 18.66 \\
\hline & & Fert2 & 3.92 & 3.99 & 0.68 & 0.65 & 21.52 & 22.46 \\
\hline & & Fert3 & 4.52 & 4.91 & 0.82 & 0.81 & 24.28 & 26.42 \\
\hline \multirow{6}{*}{ 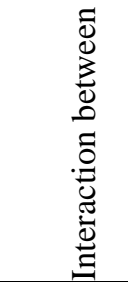 } & & Fert4 & 4.65 & 4.82 & 0.71 & 0.74 & 20.17 & 20.01 \\
\hline & \multirow{4}{*}{3640} & Fert1 & 3.78 & 3.88 & 0.52 & $\begin{array}{l}0.52 \\
\end{array}$ & 16.88 & 17.68 \\
\hline & & Fert2 & 3.98 & 4.00 & \begin{tabular}{|c|c|}
0.63 \\
\end{tabular} & 0.61 & 18.00 & 18.67 \\
\hline & & Fert3 & 4.04 & 4.12 & 0.76 & 0.67 & 20.06 & 21.70 \\
\hline & & Fert4 & 3.94 & 3.97 & $\begin{array}{c}0.70 \\
\end{array}$ & $\begin{array}{l}0.79 \\
\end{array}$ & 19.53 & 19.88 \\
\hline & \multicolumn{2}{|l|}{ LSD } & 0.56 & 0.21 & 0.05 & 0.05 & 00.73 & 00.67 \\
\hline \multicolumn{3}{|c|}{$\begin{array}{l}\text { Fert } 1=25 \%(\mathrm{NPK})+\text { Organic } \\
\text { Fert } 2=50 \%(\mathrm{NPK})+\text { Organic }\end{array}$} & & & $\begin{array}{l}\%(\mathrm{NF} \\
00 \%\end{array}$ & rgani & & \\
\hline
\end{tabular}

\section{References}

Abd El - Hakeem, A.S.2003. Response of sweet pepper crop to organic and biofertilizer application. M. Sc Thesis Fac. Agric. Moshtohor, Zagazig Univ., Egypt, pp 148.

Abd El-Ati, Y. (2000). Growth and yield of cowpea as affected by irrigation regime, phosphorus application and VA-mycorrhizae infection treatments. Assiut J. of Agric. Sci. 31(2): 21-28.

Ali , F . M. 2002 . Effect of different fertilizer sources and levels on growth, yield and quality of tomatoes. M. Sc . Thesis, Fac. Agric., Cairo Univ., Egypt.
Amer, A.H.; M. El-Desuki ; O. M. Sawan and A.M. Ibrahim (2002a). Potentiality of some snap bean (Phaseolus vulgaris, L.) varieties under different irrigation levels at Shark El-Owinat region. Egypt. J. Appl. Sci., 17(1): 327-345.

Amer, A.H.; O. M. Sawan and S. R. Salman (2002b). Water requirements of snap bean (Phaseolus vulgaris, L.) as affected by sowing date under newly reclaimed soil at Shark ElOwinat region. J. Agric. Sci. Mansoura Univ., 27(9): 6097-6107.

Ayeni, L. S.; T. O. Omole; E. O. Adeleye and S. O. Ojeniyi 2010. Integrated application of poultry manure and NPK fertilizer on performance of Tomato in Derrived Savannah transition zone of 
El-Naggar, S. A. 2004. Evaluation of tomato productivity under organic agriculture in new reclaimed sandy soil condition. M. Sc. Thesis, Fac. Agric ., Zagazig. Univ., Egypt.

Gawish, R, A.. (1992). Effect of anti-transpirations application on snap bean (Phaseolus vulgaris, L.) growth under different irrigation regimes. Menofiya J. Agric. Res., 17(3): 1285-1308.

Geetharani, P.; Parthiban, S. 2014. Effect of organic manures on growth and seed yield of tomato. Asian Journal of Horticulture; 9(1):281282.5 ref

M. Ouda. 2000a. Effect of organic and chemical fertilization on: I- Vegetative growth of tomato plants. J. Agric. Sci. Mansoura Univ. 25 (7): 4541-4554.

Mojeremane W.; Ofentse Moseki, Thembinkosi Mathowa, Gabatshele M. Legwaila and Sifanele Machacha. 2016. Yield and Yield Attributes of Tomato as Influenced by Organic Fertilizer. American Journal of Experimental Agriculture. 12(1): 1-10.

Morouelli, W. A.; L. de B. Giordano; C.A. Do S. Oliveira and O.A. Carriio (1991). Development, yield and quality of peas under different soil water tensions. Pesquisa Agropecuria Brasileira, 26(7): 1041-1047.

Morsy , M.A.; S.H. Gad El-Hak; Y.T. Abd ElMagid, and A.A. Sadek. 2001. Response of tomato to organic fertilization and mulching under El- Minia Governorate conditions. The Fifth Arabian Horticulture
Pasin, N.H.; B.G. Filho; O.S.B. Santos and V.D.C. Mello (1991). Performance of bean seeds derived from plants Subjected to water stress at two growth stages. Pesquisa Agropecuaria Brasileira, 26 (2) : 183-192.

Pasin, N.H.; B.G. Filho; O.S.B. Santos and V.D.C. Mello (1991). Performance of bean seeds derived from plants Subjected to water stress at two growth stages. Pesquisa Agropecuaria Brasileira, 26 (2) : 183-192.

Romic, D.; F. Tamic; J. Borosic; D. Dolanjski; M. Romic; M. Jankovic; J. Marusic and D. Geres (1994). Effects of irrigation on components of secondary crops yield in Coroatia. $17^{\text {th }}$ ICID European Regional Conf. on Irrigation and Drainage, Varna, Bulgaria, (1): 19-28.

Sohely Parvin; Akand, M. H.; Alam, M. B.; Haider, M. A. 2014.Effect of organic manures on growth and yield of tomato. International Journal of Sustainable Agricultural Technology; 10(1):1-6.

Yadav, R. P.; D. V. S. Chavhan and H. S. Kushwaha (1993). Effect of irrigation, phosphorus and row spacing on yield contributing characters of pea (Pisum sativum,L.). Indian J. Agron. 37(3): 617-618.

Yousafzai, S. K.; Shah Masaud Khan, Khalil ur Rehman, Junaid Khan, Sher Aslam Khan, Ijaz Hussain and Ishrat Naz. 2016. Response of tomato cultivars to different organicfertilizers under agro-climatic conditions of Mingora, Swat. Pakistan J. Agric. Res. Vol. 29 No.1. 


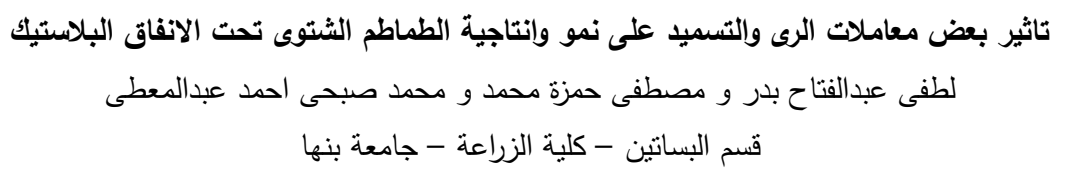

الملخص

أجريت تجربتان حقليتان بمزرعة خاصة بقرية الحوة مركز بيلا محافظة كفر الثيخ خلال الموسم الصيفي لعامى 2013- 2014على

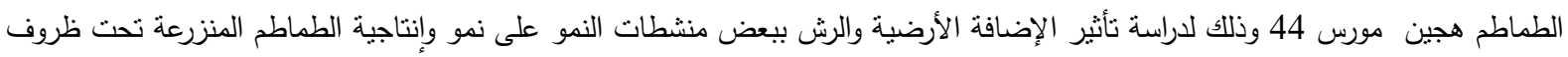

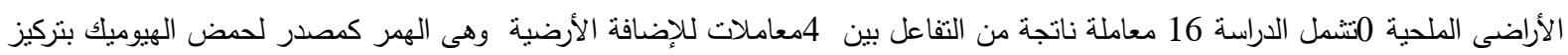
5جم /لتز والدبل ون كمصدر لمستخلص الطحالب البحرية بتركيز 5جم /لتز والفرى سال كمصدر للكالسيوم وحض الجلوناريك بتركيز 5مل/لتز بالإضافة للكنترول وكذللك 4 معاملات للرش وهى كالأتى الأمينو باور كمصدر للأحماض الأمينية 1مل/لتز والسورد كمصدر لحمض السلسيلك

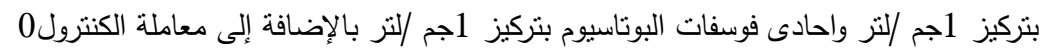

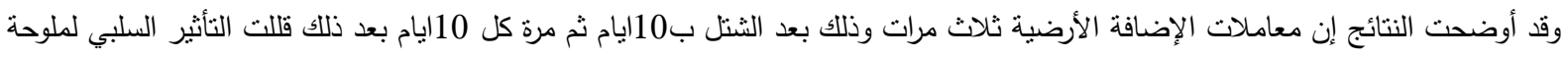
التربة وادى ذللك الى زيادة النمو الخضرى لنباتات الطماطم (طول النبات - عدد الأفرع والأوراق - الوزن الطازج والجاف وكذلك المساحة الورقية للنبات) وكذلك أدى استخدام هذه المعاملات الىى زيادة محتوى النباتات من الكلوروفيل الكلى والنيتروجين - الفسفور - الكالسيوم - البوتاسيوم والبرولين وقلل من نركيز الصوديوم فى المجموع الخضرى للنبات وكذلك ادت الى زيادة المحصول الكلى للنبات - الفدان - المحصول القابل

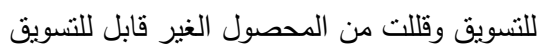
وأدت هذه المعاملات أيضا إلى تحسن صفات الجودة الطبيعية (متوسط وزن الثمرة طول وقطر الثمرة وصلابة الثمار ) و كذلك تحسين صفات الجودة الكيميائية( نسبة المواد الصلبة الذائبة- فيتامين ج - الحموضة الكلية ) بالإضافة الى ذلك فان استخدام مستخلص الطحالب البحرية أعطى أفضل النتائج في هذا الاتجاه أما بالنسبة لمعاملات الرش فقد ادى الرش بالأحماض الامينية و حمض السلسيلك واحادى فوسفات البوتاسيوم إلى زيادة معنوية فى كلا من النمو الخضرى - التركيب الكيماوى -المحصول ومكوناته وصفات الجودة الطبيعية والكيميائية للنباتات 0

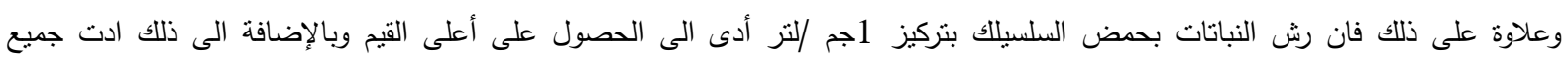

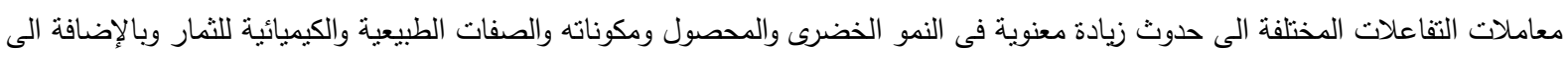
ذلك فان معاملة التفاعل بين الإضافة الأرضية بمستخلص الطحالب البحرية والرش بحمض السلسبلك كان لهما التأثير الأعلى فى هذا الاتجاه . 